\title{
Argumentação e ensino: a mediação da teoria semiolinguística do discurso
}

\section{Patricia Ferreira Neves Ribeiro}

Professora Associada da Universidade Federal Fluminense (UFF), Brasil. patricianeves@id.uff.br

\section{Diniz Duarte de Souza Duarte de Souza}

Mestre em Estudos de Linguagem pela Universidade Federal Fluminense (UFF), Brasil. dinizduartes@gmail.com

Resumo: À luz dos pressupostos do contrato comunicativo oferecidos pela Teoria Semiolinguística do Discurso e do ensino organizado por uma Sequência Didática, apresentamos, neste estudo, uma abordagem teórico-metodológica que leva o alunado ao aprimoramento efetivo de sua capacidade de comunicação na modalidade escrita da língua sob o modo de organização argumentativo. Para a construção da Sequência Didática proposta neste trabalho, pautamo-nos não só nas contribuições de Charaudeau (2004) e Schneuwly e Dolz (2011), relativamente ao conceito de gênero discursivo, como também nas de Charaudeau (2014) e Emediato (2007) concernentes a aspectos teóricos relativos ao parâmetro consistência argumentativa. Como resultado da pesquisa empreendida em uma turma do primeiro ano do Ensino Médio de uma escola pública de Niterói - RJ, comprovamos os acertos de um ensino de produção textual argumentativa baseado em uma Sequência Didática fomentada por pressupostos semiolinguísticos.

Palavras-chave: Semiolinguística. Sequência didática. Carta de leitor. Consistência argumentativa.

Abstract: Based on presuppositions of the communicative contract offered by the Semiolinguistic Theory of Discourse and of a teaching organized by a Didactic Sequence, we present, in this study, a theoretical-methodological approach that leads the pupil to the effective improvement of his or her communication capacity in the written form of the language under the mode of argumentative organization. To construction of the Didactic Sequence proposed within this work, we have not only the contributions of Charaudeau (2004) and Schneuwly and Dolz (2011), but also of Charaudeau (2014) and Emediato (2007) concerning theoretical aspects related to the argumentative consistency parameter. As a result of the research carried out in a high school class of a public school in Niterói - RJ, we verified the correctness of a textual argumentative production teaching based on a didactic sequence fostered by semiolinguistic assumptions.

Keywords: Semiolinguistic. Didatic Sequence. Reader's letter. Argumentative consistency. 
Introdução

Os mais recentes índices apresentados no escopo do Exame Nacional do Ensino Médio (ENEM), no que se refere à produção textual argumentativa do alunado brasileiro, têm se revelado bastante negativos. Em 2017, por exemplo, apenas 53 alunos, em um total de 4.725 .330 , alcançaram a nota máxima na redação, enquanto cerca de 309.157 estudantes obtiveram nota zero em suas produções textuais. Descontadas as críticas e ponderações que se possa fazer ao exame focalizado e aos resultados decorrentes, o presente trabalho configura-se, em vista dessa problemática, como uma pesquisa que se preocupa com o ensino de produção textual na educação básica. No bojo dessa preocupação mais específica, o texto é tomado segundo a concepção postulada pelo pesquisador francês Patrick Charaudeau, segundo a qual é "o resultado de uma combinação de certas condições de produção com operações de discursivização, isto é, com operações de construção do discurso" (2005, p. 68).

Nessa direção, este trabalho trata da linguagem em dimensão discursiva, não sendo as ações linguísticas abordadas meramente em relação ao funcionamento gramatical. Antes, tais ações são consideradas na correlação que estabelecem com aspectos sociais e históricos. Neste estudo, são consideradas, dessa forma, tanto as condições de produção quanto as operações de discursivização em jogo na atividade de construção textual.

Diante disso coloca-se uma questão essencial a esta pesquisa centrada sobre a interface argumentação, discurso e ensino: "Como interceder para que se possa ampliar a competência comunicativa dos alunos em modalidade escrita estruturada segundo o modo argumentativo do discurso?". Neste estudo, partimos da suposição de que o ensino da argumentação escrita, mediado pelo conhecimento das restrições atinentes a determinado contrato comunicativo que a preside, pode auxiliar o educando a se expressar melhor. Ancorado nessa hipótese, o presente trabalho visa refletir sobre mecanismos contratuais que possam ajudar os educandos a desenvolverem sua capacidade de produzir textos escritos filiados ao modo argumentativo e oferecer uma forma prática de ensino de produção textual pautada na superação dos principais problemas encontrados nas produções dos estudantes.

À luz dos pressupostos do contrato comunicativo oferecidos pela Teoria Semiolinguística do Discurso, do linguista francês Patrick Charaudeau, e de um 
ensino organizado por uma Sequência Didática, advindo dos estudos do grupo de Genebra, liderado por Bernard Schneuwly e Joaquim Dolz, apresenta-se, nesta pesquisa, uma abordagem teórico-metodológica que leva o alunado ao aprimoramento efetivo de sua capacidade de comunicação, na modalidade escrita da língua, organizada segundo o modo argumentativo e filiada ao gênero discursivo carta de leitor.

O cenário eleito para esta pesquisa é o Colégio Estadual Leopoldo Fróes, situado na cidade de Niterói-RJ. Embora o estudo tenha se centrado sobre uma turma do primeiro ano do Ensino Médio, com cerca de trinta alunos, apresentamos, neste artigo, os resultados concernentes às produções de um dos discentes da turma, resultados esses que mapeiam, em termos gerais, o que foi alcançado pelo grupo em sua totalidade. Visando comprovar a nossa hipótese, aplicamos uma Sequência Didática integrada pelas postulações teóricas da Análise Semiolinguística do Discurso, com vistas à produção do gênero discursivo carta de leitor. O objetivo da aplicação da Sequência Didática, por nós, elaborada e aplicada, é provar que os pilares da Semiolinguística, integrados à referida Sequência, podem auxiliar no ensino da produção textual e contribuir para a inserção cultural e social do aprendiz.

Quanto à construção da Sequência Didática propriamente dita, destacamos dois operadores didáticos fundamentais à realização do trabalho, a saber: o gênero discursivo carta de leitor e o tema transversal Ética. O gênero carta de leitor foi escolhido por ser um gênero por meio do qual os alunos podem manifestar um ponto de vista e expressar seus sentimentos sobre determinado assunto. Já a escolha do tema encontrou justificativa na própria orientação dos Parâmetros Curriculares Nacionais (2001), mencionado como um que deve ser trabalhado em aula por sua larga importância social. Sendo esse um tema bastante abrangente, considerou-se a necessidade de focalizálo à luz de alguma especificação. Dentre as inúmeras possibilidades encontradas, elegemos o tema mais específico da Violência, declarado pelos alunos da turma em análise como em larga evidência nos jornais da atualidade e nas conversas e realidade cotidiana dos próprios estudantes. Na discussão sobre a questão da Violência - que se põe como infração àquilo que orienta a boa conduta humana - o tema transversal Ética emerge necessariamente. 


\section{A construção do trabalho: aspectos teórico-metodológicos}

Neste trabalho, buscamos, pelo fio de uma Sequência Didática centrada sobre o gênero carta de leitor, ajudar o aluno a compreender as condições que devem iluminar seus comportamentos linguageiros no momento da confecção de textos escritos. O reconhecimento da influência do gênero na prática de linguagem e o conhecimento dos comportamentos que ele demanda são extremamente relevantes para que o alunado possa visualizar e pensar sobre o contexto e o propósito de cada ato de linguagem e as formas linguísticas a serem acionadas em correspondência. Todavia, vale ressaltar que uma abordagem discursiva do ensino de produção textual, feita por intermédio do gênero, demanda uma sistematização.

A Sequência Didática trata-se de "um conjunto de atividades escolares organizadas, de maneira sistemática, em torno de um gênero textual oral ou escrito" (DOLZ; NOVERRAZ; SCHNEUWLY, 2011, p. 97), sendo a metodologia de ensino, por intermédio da Sequência Didática, baseada no pressuposto de que o gênero é o alicerce da aprendizagem, em correspondência ao contrato comunicativo de base.

A apresentação da situação é o momento inicial da Sequência Didática e tem os seguintes propósitos: a) compartilhar a proposta de trabalho junto aos alunos, levando-os a compreenderem a situação de comunicação na qual devem agir; b) sondar o conhecimento prévio dos alunos sobre os aspectos de organização do gênero a ser trabalhado e do conteúdo a ser tratado; c) ler diferentes textos do gênero escolhido, a fim de fornecer aos alunos informações necessárias do projeto comunicativo visado, relativamente às características do gênero e ao tema.

Segundo os autores, a apresentação da situação inicial é facilitada se o professor propuser projetos efetivamente realizáveis. De acordo com Schneuwly, Noverraz e Dolz (2011, p, 84), ao término desta etapa, o aluno deve estar apto a responder às seguintes perguntas: "Qual é o gênero abordado?”, “A quem se dirige a produção?”, “Que forma assumirá o texto?” e “Quem participará da produção?”. Sob esses questionamentos, o professor pode, a nosso ver, abordar o gênero com base nos pressupostos da Teoria Semiolinguística do Discurso. Nesta reflexão, o docente terá a possibilidade de discutir a respeito das regras e restrições que envolvem dado gênero textual/discursivo à luz dos conceitos advindos do contrato de comunicação, definido no seio da Semiolinguística como "conjunto de condições nas quais 
se realiza qualquer ato de comunicação" (CHARAUDEAU e MAINGUENEAU, 2004, p.132), sendo essas condições definidoras do gênero.

Ao produzir um texto, o aluno deve estar consciente não só de sua atuação discursiva, como também da de seu destinatário. O educador pode levar o educando a pensar sobre o "EU" e o "TU" do circuito interno de encenação comunicativa envolvidos em determinado contrato comunicativo. Além disso, o docente tem a oportunidade de dar ênfase à finalidade do texto e ao modo de organização correspondente. O segundo momento desta primeira etapa é a dimensão dos conteúdos. O educador poderá iniciar um debate e apresentar o que pessoas célebres pensam sobre o tema focalizado. Neste instante, o professor pode trabalhar à luz de Semiolinguística ao levar o aluno a pensar sobre a legitimidade e a credibilidade de determinada personalidade. Tal reflexão pode ser associada a uma discussão sobre a temática e ajudar o aluno a produzir o texto de maneira mais reflexiva e profunda. Sendo assim, esse momento inaugural pode estar intrinsecamente relacionado aos conceitos semiolinguísticos, visto que os propósitos estruturados nesse nível da Sequência Didática podem ser alicerçados pelos pressupostos teóricos da Análise do Discurso.

Após a apresentação da situação inicial, o aluno fará sua primeira produção, sendo esse o segundo passo da Sequência Didática. Os estudantes poderão elaborar um texto oral ou escrito que servirá como referência para o professor entender a situação da turma. Já, nos módulos (etapas subsequentes), a superação dos problemas apresentados anteriormente será trabalhada de forma minuciosa. Nesse estágio, o educador apresentará tarefas orais ou escritas que desafiem os alunos e os ajudem a vencer as dificuldades. Sob esse prisma, destaca-se que três pontos devem nortear a construção dos módulos: as dificuldades de expressão oral e escrita; a aplicação de exercícios variados; a capitalização das aquisições (DOLZ, NOVERRAZ, SCHNEUWLY, 2011, p.88). Neste contexto, o professor pode levar o estudante a refletir sobre as características que envolvem a situação dada e, dessa forma, pensar sobre o gênero discursivo e o contrato comunicativo de base.

A presença de conhecimentos advindos de uma abordagem Semiolinguística do Discurso parece ser de grande valia nesta etapa inicial dos módulos, como os relacionados a algumas questões atinentes à representação da situação comunicativa, a saber: "Para quem escrevo?”, "Para que escrevo?", “Como escrevo?" e “De onde escrevo?". Trazer tais questionamentos à tona, nesse momento inaugural do primeiro módulo da 
Sequência Didática, auxiliará o educando a refletir sobre as restrições e as estratégias discursivas típicas da situação comunicativa em que o aluno encontre-se inserido, ajudando-o a se expressar melhor, a aperfeiçoar suas habilidades linguísticas e a desenvolver um olhar crítico sobre o texto.

$\mathrm{Na}$ coordenação entre preocupações voltadas à representação da situação comunicativa, à elaboração dos conteúdos, ao planejamento e à realização do texto com a aplicação não só de atividades de observação e de análise de textos e de tarefas simplificadas de produções de textos, como também de aquisição de uma tomada de consciência sobre o gênero, está o delineamento dos módulos de uma Sequência Didática.

Por fim, a última etapa da Sequência Didática é a produção final. Neste momento, o educando terá a oportunidade de colocar em prática o conhecimento adquirido ao longo da Sequência. Vale lembrar que a fase final serve como apreciação do aprendizado não somente para o professor, mas principalmente para o aluno.

Para melhor elucidação do passo a passo da Sequência Didática elaborada para esta pesquisa, apresentamos o Quadro 1:

\section{Quadro 1 - Sequência didática}

\begin{tabular}{|l|l|l|}
\hline \multicolumn{1}{|c|}{ Etapa } & \multicolumn{1}{|c|}{ Produção escrita analisada } & \multicolumn{1}{c|}{ Abordagem } \\
\hline $\begin{array}{l}\text { Situação } \\
\text { inicial }\end{array}$ & $\begin{array}{l}\text { Produção Textual (1): Carta à } \\
\text { Marizete. }\end{array}$ & $\begin{array}{l}\text { Debate sobre o tema./ b) Produção } \\
\text { textual a partir do conhecimento prévio. }\end{array}$ \\
\hline $\begin{array}{l}\text { Produção } \\
\text { Inicial }\end{array}$ & $\begin{array}{l}\text { Produção Textual (2): Carta de } \\
\text { leitor sobre a Eutanásia. }\end{array}$ & $\begin{array}{l}\text { Debate sobre o tema e o gênero./b) } \\
\text { Produção textual a partir das discussões } \\
\text { realizadas em aula. }\end{array}$ \\
\hline $\begin{array}{l}\text { Módulo 1e e } \\
\text { Módulo 2 }\end{array}$ & $\begin{array}{l}\text { Exercícios e Produção Textual } \\
\text { (3) referentes à consistência } \\
\text { argumentativa: Carta de leitor } \\
\text { sobre a Violência Urbana. }\end{array}$ & $\begin{array}{l}\text { Debate sobre o tema, o gênero e as } \\
\text { produções anteriores./ b) Produção } \\
\text { textual a partir das discussões realizadas } \\
\text { em aula e dos exercícios propostos. }\end{array}$ \\
\hline $\begin{array}{l}\text { Produção } \\
\text { Final }\end{array}$ & $\begin{array}{l}\text { Produção Textual (4): Carta de } \\
\text { leitor sobre a Origem da } \\
\text { violência e seu crescimento. }\end{array}$ & $\begin{array}{l}\text { Debate sobre o tema, o gênero e as } \\
\text { produções anteriores./ b) Produção } \\
\text { textual a partir das discussões realizadas } \\
\text { e dos exercícios propostos durante toda a } \\
\text { aplicação da Sequência Didática. }\end{array}$ \\
\hline
\end{tabular}

Fonte: elaboração própria

As produções iniciais do estudante focalizado, aqui ficticiamente denominado por Anderson, mostraram a necessidade de se centrar o trabalho, sobretudo, sobre a consistência argumentativa, concernente ao 
espaço da finalidade e do propósito temático. A consistência argumentativa, neste trabalho, está sendo tomada no sentido de um respeito à macroestrutura da construção argumentativa e a um aprofundamento de argumentos. Tal consistência está considerada no âmbito do modo de organização argumentativo, o que para Charaudeau (2014, p. 207) significa que "a argumentação é o resultado de uma combinação entre diferentes componentes que dependem de uma situação que tem finalidade persuasiva". Ainda a consistência argumentativa está sendo vista no escopo do modo de tematização, o que, para o teórico, quer dizer a seleção e desenvolvimento do tema e de temas mais específicos no interior da argumentação, com base em saberes de crença e de conhecimento.

No próximo momento da pesquisa, elucidaremos os problemas e avanços detectados a partir da análise das produções textuais de um aluno da turma, com vistas a conferir as possíveis aquisições capitalizadas no bojo de um trabalho respaldado em princípios teóricos da Semiolinguística e em procedimentos oriundos da Sequência Didática.

\section{A construção da análise: argumentações mediadas}

A análise das produções textuais será feita detalhadamente uma a uma, respeitando-se as etapas da Sequência Didática em que foram produzidas.

De acordo com Charaudeau (2005, p.16), “Todo ato de linguagem é um fenômeno de troca entre dois parceiros (quer estejam diante um do outro ou não)". Em uma situação comunicativa, os sujeitos são dotados de intencionalidade, sendo assim, o discurso não é construído de maneira arbitrária. $\mathrm{Na}$ troca entre os parceiros supramencionada, há, permanentemente, repertório cultural em circulação e um sujeito em busca de persuadir o outro.

Durante a produção de uma carta de leitor, o outro parceiro (leitor) não está presente fisicamente. Sendo assim, os estudantes - ao serem alçados à condição de enunciadores de cartas de leitor - têm tempo para refletirem sobre um princípio básico da comunicação: a finalidade. Ao escreverem seus textos, os alunos devem sempre se fazer a seguinte pergunta: "Estamos aqui para dizer ou fazer o quê?” (CHARAUDEAU, 2005, p.19). Ao pensar sobre essa pergunta e mobilizar recursos linguageiros correspondentes à resposta dada, acreditamos que os estudantes acabem por conferir mais consistência aos seus textos. 


\section{$\mathrm{EI} D \bar{\alpha} \mathrm{A}$}

Revista Eletrônica de Estudos Integrados em Discurso e Argumentação, Ilhéus, n. 17, jul./dez. 2018

Ao avaliar a (in)consistência argumentativa nas produções textuais do estudante Anderson, fundamentaremos os nossos critérios nas definições de Charaudeau (2014) quanto ao modo de organização argumentativo do discurso. Primeiramente, o linguista afirma que o modo argumentativo "está em contato apenas com um saber que tenta levar em conta a experiência humana, através de certas operações do pensamento" (2014, p.201). Além disso, podemos notar a importância de saber argumentar consistentemente, pois "uma argumentação pode ser anulada em seu próprio fundamento ou, em todo caso, anulada em sua validade. A argumentação desaparece sob a contestação se não logra superá-la." (2014, p.201).

Tendo em vista a relevância de uma argumentação consistente, Charaudeau (2014, p.205) descreve os elementos necessários para isso, afirmando que a argumentação é definida segundo uma relação triangular entre:

\footnotetext{
- uma proposta sobre o mundo que provoque um questionamento, em alguém, quanto à sua legitimidade (um questionamento quanto à legitimidade da proposta).

- um sujeito que se engaje em relação a esse questionamento (convicção) e desenvolva um raciocínio para tentar estabelecer uma verdade (quer seja próprio ou universal, quer se trate de uma simples aceitabilidade ou de uma legitimidade) quanto a essa proposta.

- um outro sujeito que, relacionado com a mesma proposta, questionamento e verdade, constitua-se no alvo da argumentação. Trata-se da pessoa a que se dirige o sujeito que argumenta, na esperança de conduzi-la a compartilhar da mesma verdade (persuasão), sabendo que ela pode aceitar (ficar a favor) ou refutar (ficar contra) a argumentação.
}

Desta maneira, observaremos, sob este parâmetro, as características supramencionadas para uma argumentação consistente nas produções textuais do estudante eleito.

A primeira carta escrita pelo educando foi direcionada à interlocutora Marizete. Após exibição da letra da canção "O homem que não tinha nada", de dois cantores muito presentes no cotidiano dos alunos: Projota e Negra Li, a qual conta a história de Josué, um homem trabalhador que deixou sua família para trabalhar e não retornou, pois fora vítima de assalto seguido de assassinato em uma rua da cidade, solicitou-se aos alunos que escrevessem uma carta à Marizete, esposa de Josué, acerca da violência urbana. Neste 
$\mathrm{EI} \sqcap \mathrm{dA}$

Revista Eletrônica de Estudos Integrados em Discurso e Argumentação, Ilhéus, n. 17, jul./dez. 2018

texto, o aluno comentou sobre a fatalidade que atingiu a família da dona de casa. Anderson apresentou problemas diante da proposta do exercício, pois o estudante não escreveu uma carta para Marizete, mas um texto descrevendo o que diria à Marizete, conforme podemos observar a seguir:

Diria para ela ser forte, pois seu pai também foi; para manter a fé, independente do que houver e jamais abandonar os objetivos, buscando sempre tentar atingílos sem derrubar ninguém para que o mundo seja um lugar melhor e nenhuma outra família passe também por uma situação trágica que ela viveu.

Ao observar a carta do estudante Anderson, podemos notar que ele expõe a seguinte tese: "Seja forte!". Todavia, o texto do discente não é composto por argumentos que possam fortalecer ou justificar sua tese, resultando, desta maneira, em uma carta inconsistente e pouco persuasiva.

Podemos notar, na carta, que ele não desenvolve sua argumentação e isso resulta em um texto raso e sem consistência. O educando escreve que Marizete precisa ser forte porque seu pai também sempre foi. Devido a essa afirmação, surgem as seguintes questões: "Por que ela tem que ser forte igual ao pai?”, “Qual é o fundamento que explica essa afirmação?” Desta maneira, podemos perceber que seu argumento é baseado em uma relação de causalidade infundada.

Outro aspecto relevante dos trechos destacados diz respeito ao emprego de um argumento de finalidade sem fundamentação. $O$ autor pede para que nunca abandone a sua família para que o mundo seja melhor. Então, surge um novo questionamento: "O mundo será melhor se ela não abandonar a família?". Além dessas duas características, o discente não escreve uma conclusão para reforçar seus argumentos. Com base nesta análise, podemos perceber que o aluno precisa aprimorar sua produção textual, pois sua carta é composta por argumentos superficiais e sem uma conclusão definida.

Após essa primeira produção, o aluno escreveu uma segunda produção textual, na etapa da produção inicial, cuja transcrição vem a seguir:

11 de outubro de 2016 Eutanásia e Ortotanásia

A forma ativa e passiva da Eutanásia

A Eutanásia é um a prática que e aplica em uma pessoa com uma doença incurável e/ou estado terminal, também sendo aplicada a uma pessoa com sofrimento constante e respira por aparelhos à uma morte sem dor ou sofrimento. 
Há duas práticas da Eutanásia, a Eutanásia ativa que é a aplicada à pessoas em estado terminal / sofrimento constante, e a Eutanásia passiva, que é mais conhecida como Ortotanásia, que por sua vez é uma prática onde os médicos não aplicam a morte aos pacientes que estão em sofrimento ou estado terminal, eles simplesmente "deixam" o paciente naquela agonia até morrer.

A prática da Eutanásia ativa, embora seja um crime no Brasil, deveria ser utilizada e legalizada no país, pois existem muitas pessoas em estado vegetativo, respirando por meio de aparelhos e sofrendo. Na minha opinião, a Eutanásia é a solução, pois um ser humano não merece sofrer e a Eutanásia dá ao paciente uma morte sem dor ou sofrimento.

A consistência argumentativa pode ser observada mais profundamente na segunda produção textual, em que o estudante apresentou sua opinião quanto à Eutanásia e evidenciou argumentos para sustentar seu posicionamento. Charaudeau (2014, p.207) afirma que argumentar é uma atividade discursiva que participa de uma dupla busca pelo sujeito argumentante. Segundo o autor, há no sujeito argumentante (os educandos) uma "busca de racionalidade" e uma "busca de influência". A primeira busca "tende a um ideal de verdade quanto à explicação de fenômenos do universo"; a segunda "tende a um ideal de persuasão, o qual consiste em compartilhar com o outro (interlocutor ou destinatário) certo universo de discurso até o ponto em que este último seja levado a ter as mesmas propostas (atingindo o objetivo da comunicação)". Em vista disso, avaliaremos a carta do aluno levando em consideração a relação triangular (proposta sobre o mundo, sujeito argumentante e sujeito alvo) - referente à consistência argumentativa - e a dupla busca supramencionada.

A segunda carta de Anderson, cujo tema girou sobre a questão polêmica “Eutanásia: problema ou solução?”, considerada como da ordem da violência por alguns grupos, apresentou uma evolução expressiva. O discente, após a leitura de reportagens sobre a Eutanásia e as vantagens e desvantagens dessa tomada de decisão, iniciou seu texto respondendo a uma matéria (O Globo 09/12/2016) sobre a Eutanásia ser considerada crime ou não e explicando - no segundo parágrafo - minuciosamente a diferença entre Eutanásia e Ortotanásia.

Ao demonstrar domínio sobre o assunto, o aluno apresenta um texto mais dotado de credibilidade. Vale lembrar que Charaudeau (2006, p.67) explica a credibilidade como a capacidade do sujeito de dizer ou de fazer. Ao demonstrar domínio sobre o assunto, o educando busca agregar credibilidade 
ao seu texto, comprovar sua capacidade de escrever sobre o tema proposto e, consequentemente, convencer o leitor de que o seu ponto de vista é o mais apropriado.

Após apresentar as definições do tema, o discente expressa sua opinião sobre o assunto: "A prática da Eutanásia ativa, embora seja um crime no Brasil, deveria ser utilizada e legalizada no país [...]”. Em seguida, o aluno expõe seu argumento e reitera sua opinião no trecho negritado acima e transcrito a seguir: “... pois existem muitas pessoas em estado vegetativo, respirando por meio de aparelhos e sofrendo. Na minha opinião, a Eutanásia é a solução, pois um ser humano não merece sofrer e a Eutanásia dá ao paciente uma morte sem dor ou sofrimento". Assim, o estudante demonstra seu posicionamento. Ele apresenta seu raciocínio para tentar estabelecer uma verdade ("A Eutanásia deve ser legalizada no Brasil”) quanto à proposta temática. Entretanto, sua "busca de racionalidade" e sua "busca de influência" foram comprometidas pela falta de desenvolvimento dos seus argumentos. A explicação sobre seu ponto de vista e a busca pela persuasão do interlocutor foram prejudicadas devido à superficialidade da sua argumentação.

Anderson defende a legalização da Eutanásia com base nos dados de inúmeros pacientes sofrendo em estado vegetativo que não merecem essa condição. O discente tem um argumento coerente, relevante e válido com relação à Eutanásia, todavia apenas o apresenta, mas não o desenvolve. Essa circularidade resulta em uma argumentação frágil e inconsistente.

Ao discorrer sobre a estrutura da argumentação proposta por Charaudeau, relacionada à progressão argumentativa e ao propósito temático, Wander Emediato (2007, p. 162) afirma que "não se pode argumentar bem sem apresentar, em um determinado momento, argumentos que possam ser aceitos como plausíveis e aceitáveis pelo interlocutor". Anderson expõe seu argumento, porém não apresenta todos os alicerces necessários para uma boa argumentação, conforme defende Emediato: "A formulação dos argumentos será, portanto, a parte da argumentação relativa aos tipos de provas, à lógica dos raciocínios e princípios de explicação e justificação que fundamentam a tese ou afirmação" (2007, p.162).

Ao analisar a carta de Anderson, percebemos que o estudante apresenta uma prova consistente no texto, porém sua carta é composta por 
$\mathrm{EI} \square \mathrm{dA}$

Revista Eletrônica de Estudos Integrados em Discurso e Argumentação, Ilhéus, n. 17, jul./dez. 2018

circularidade que não aponta para o desenvolvimento da prova, conforme o trecho correspondente ao último parágrafo.

Dessa maneira, podemos perceber que há ainda muitos mecanismos linguísticos referentes à argumentação a serem desenvolvidos. Entretanto, a diferença entre a primeira e a segunda carta é notória. O estudante demonstrou um relevante progresso quanto à organização da argumentação na sua produção textual, isto é, demonstrou um amplo conhecimento sobre o conteúdo inicialmente e depois apresentou sua tese. Todavia, ele ainda precisa aprender a como utilizar os alicerces da argumentação supramencionados para que possam tornar sua produção mais consistente e agregar mais credibilidade à sua argumentação.

Na fase do módulo1, os educandos refletiram sobre alguns trechos das redações anteriores e algumas situações do dia a dia, nas quais eles precisavam convencer outra pessoa acerca de alguma ideia levantada. Neste momento, eles começaram a pensar sobre o que é uma boa e uma má argumentação em um texto. Quanto à expressão "boa argumentação", Charaudeau (2014, p. 207) afirma que "a argumentação é o resultado textual de uma combinação entre diferentes componentes que dependem de uma situação que tem finalidade persuasiva" e que "é nesse quadro que poderão ser utilizadas as expressões 'desenvolver uma boa argumentação', 'ter bons argumentos', 'bem argumentar”'.

Pensando justamente nos "diferentes componentes", após um debate sobre argumentos bons e ruins, passou-se a uma discussão sobre a argumentação presente em uma tirinha do Calvin. O objetivo desse momento inicial foi pensar sobre a importância da argumentação e as possíveis estratégias discursivas para aprimorá-la. Após esse período de reflexão sobre a argumentação, debatemos sobre o tema da aula por intermédio de vídeos e reportagens acerca de crimes cometidos por pessoas que, trajando roupas de palhaços macabros, espalhavam medo pelas ruas de grandes cidades no período noturno (O Globo-11/10/2016). Em vista dessa temática, pedimos aos alunos que escrevessem uma carta de leitor comentando os últimos fatos ocorridos frente aos atos dos referidos palhaços e manifestassem sua opinião sobre o assunto.

Segue a carta do discente: 
$1^{\circ}$ de Novembro de 2016 O que nos torna tão violentos?

É notório ver que a violência cresceu; todos os dias vemos e ouvimos através dos meios de comunicação algum tipo de relato sobre violência que ocorreu, e na maioria das vezes esses tipos de violência são cometidos por jovens de menos de 29 anos que moram em favelas ou lugares mais desprezados pela sociedade. Mas o que os leva a estarem envolvidos com esses tipos de violência?

De acordo com Marcelo Andriotti, diretor da ONG Favela Mundo "As cidades foram segmentadas entre os que têm e os que não têm direito a itens fundamentais para um desenvolvimento pleno e sadio. [...] Tudo de melhor estava em uma parte da cidade e o restante ficava com o que sobrava. [...] Começaram a queres essas coisas também. E, se não podiam tê-las pelas maneiras tradicionais, o fariam de alguma outra forma. Dariam um "jeito", mesmo errado. Enquanto uns baseavam o seu ser naquilo que tinham, outros 0 fizeram através do poder, pela força bruta."

Como um jovem, sei como a pressão social, o almejo pelo poder, a falta de atenção dos pais e até a discriminação atrai ira à cabeça e nos deixa instáveis, o comportamento desses jovens que praticam a violência pode ser talvez até um pedido de socorro ou a busca para obter uma vida melhor por não ter direito a milhares de coisas que para alguns jovens de classe média alta é completamente acessível.

A realidade da juventude que convive em favelas é precária e assustadora, isto tudo sempre obtém certo tipo de influência, uma vez onde o destino de vários jovens é morrer de fome, por bala perdida ou por drogas já que não têm acesso a uma qualidade de educação e vida melhores.

O estudante Anderson produziu sua carta de leitor utilizando mecanismos linguísticos que organizaram o seu texto e reforçaram sua opinião. O aluno introduziu seu discurso comentando sobre a realidade em que vivemos. Em seguida, ainda no primeiro parágrafo, o discente incita o leitor a refletir sobre a temática e instaura a tese por intermédio de uma questão. Vale ressaltar que, em temos de finalidade, podemos observar respeito à macroestrutura argumentativa subdividindo o texto em: proposta, tese, argumentos e conclusão. Além disso, há já produção de maior consistência argumentativa em seu texto.

O discente começa a sua resposta mencionando um especialista que tem autoridade para tratar do assunto, o diretor da ONG Favela Mundo. Ao apresentar o depoimento de um expert na temática proposta, Anderson produz um efeito de autenticidade em seu texto e, consequentemente, escreve uma carta com maior consistência argumentativa. Quanto à citação de dados ou referências em textos, Charaudeau (2014, p.240) afirma que "a 
citação consiste em referir-se, o mais fielmente possível [...] às emissões escritas ou orais de um outro locutor, diferente daquele que cita, para produzir na argumentação um efeito de autenticidade".

Dessa maneira, podemos notar que Anderson iniciou sua carta de leitor de forma completamente diferente das anteriores, pois, nos parágrafos iniciais, o aluno conseguiu apresentar o contexto da temática, incitar o leitor à reflexão e agregar maior credibilidade e legitimidade ao texto por intermédio da citação.

Vale ressaltar que, diferentemente das cartas de leitor anteriores, o aluno foi capaz de, nesta etapa, respeitar a macroestrutura do texto; portanto, observou com sucesso os aspectos acerca da finalidade. Além disso, o estudante foi capaz de escrever uma carta com maior consistência argumentativa, respeitando, desse modo, o propósito temático.

A produção final constitui a última etapa da Sequência Didática. Nessa fase, o aluno tem a oportunidade de demonstrar, por intermédio do seu texto, os conhecimentos adquiridos ao logo de todo o processo. Em seguida, apresentamos a última carta de leitor produzida pelo estudante Anderson, no bojo da Sequência Didática implementada, cuja escritura foi motivada pela leitura de duas notícias publicadas acerca da violência em Niterói (O Globo e 0 Fluminense - 30/10/2016).

De onde vem a violência?

Em toda parte há violência, isso é inegável; agressões físicas, psicológicas, crimes, terror, estupros e etc. No Brasil, especificamente em Niterói, Rj, a violência tem crescido drasticamente ao longo dos anos e colocado a sociedade assustada com tudo o que tem ocorrido ultimamente. Mas de onde as pessoas ao redor do mundo tiram tanto ódio para cometer tanta violência?

A violência pode ser tanto cultural quanto biológica, vários fatos contribuem para originalizá-la em nosso meio, isso vem desde o reino animal com o macho brigando para conquistar a fêmea, e ela por sua vez defendendo o seu território de predadores que também fazem parte desse meio de violência.

De acordo com o geneticista Oswaldo Frota-Pessoa "há uma predisposição genética para a agressividade", mas ele adverte que: "Não existe um gene que seja única e exclusivamente responsável por uma crise de cólera". Segundo Frota-Pessoa, durante a evolução, os genes dos indivíduos de qualquer espécie que agiram mais adequadamente em relação ao meio foram perpetuados. "Por isso, como a maioria das características físicas e comportamentais normais, a predisposição para agressividade também é transmitida por um grupo de 
genes". Ou seja, estes apenas determinam a probabilidade de a pessoa ser agressiva. O resto é com a vida.

“Alguém com alta predisposição para a violência e que vive num meio violento é claro que terá maiores oportunidades de agir com agressividade, exemplifica o genecista. Mas uma educação ultra pacífica possui as chances de qualquer um ser agressivo. $O$ ambiente e a biologia interagem."

Logo, a violência vem tanto do berço pela nossa própria personalidade e índole como vem de onde convivemos e nosso ambiente; a educação ajuda a diminuir os impulsos agressivos, porém as características violentas tende a vir pela própria vida, como vingança ou ódio que nos leva a um patamar maior na violência que gera pessoas de personalidade fria e calculista.

O estudante começa sua carta com o seguinte título: "De onde vem a violência?". Iniciar um texto com uma pergunta é uma estratégia com muito valor argumentativo, pois, além de incitar o leitor, a questão orienta as respostas que serão apresentadas durante o texto, conforme afirmam Koch e Elias (2016, p. 168), que concordam que mais importante do que saber responder é saber perguntar e completam dizendo que "se o espaço destinado à pergunta é no início do texto, o peso é ainda maior para essa estratégia, pois é ela quem vai orientar as respostas que hão de vir no desenrolar do texto".

Em vista desse postulado, podemos perceber que o educando iniciou seu texto com uma pertinente estratégia argumentativa. Em seguida, o discente relata o crescimento da violência na sociedade e aborda o caos que a população da sua cidade tem vivido. Vale ressaltar que o aluno começa seu texto não dando margem a questionamento sobre sua resposta, pois, após afirmar que há violência em toda parte, ele já escreve que isso "é inegável” e concorda com a proposta consensual sobre a violência nas grandes cidades. Em seguida, Anderson descreve a reação do povo em relação aos fatos e ressalta que a grande maioria desses crimes é feita por jovens.

Além da pergunta no título do texto, o educando termina o parágrafo introdutório com um novo questionamento: "Mas de onde as pessoas ao redor do mundo tiram tanto ódio para cometer tanta violência?". Charaudeau (2014, p.242) afirma que o questionamento tem valor argumentativo e "permite ao questionador mostrar que ele sabe e assegurar eventualmente sua superioridade sobre aquele que é questionado". Desta maneira, o estudante assume uma posição de sabedor e, concomitantemente, de autoridade, pois responderá à pergunta proposta no texto. 
Diferentemente das cartas iniciais compostas por argumentos advindos do senso comum, o estudante inicia a argumentação do seu texto demonstrando domínio sobre o assunto. $O$ educando responde à pergunta relatando que a violência pode ser cultural ou biológica. Em busca de fortalecer seu argumento, ele expõe fatos, no segundo parágrafo, que corroboram para o seu pensamento quanto à origem da violência. $O$ aluno desenvolve sua argumentação sobre a origem da violência apresentando "fatos atestados", sendo esses definidos como argumentos empíricos baseados em acontecimentos observados e relatados. Wander Emediato (2007, p. 173) considera que esses fatos podem pesar significativamente sobre argumentos e opiniões, ressalvando que não são incontestáveis. Em vista disso, apesar de o aluno ter iniciado sua produção textual com uma argumentação melhor fundamentada do que a das cartas anteriores, o educando ainda precisa planejar outras estratégias argumentativas que possam trazer mais credibilidade e, concomitantemente, captar o leitor.

Nos dois parágrafos seguintes, o educando menciona um especialista no assunto para reforçar o ponto de vista defendido no texto. Ao apresentar um expert no tema, o aluno agrega maior credibilidade à sua carta de leitor. Koch e Elias (2016, p.43) afirmam que uma citação direta funciona como recurso de autoridade no texto. Vale ressaltar que, além de mencionar o geneticista, o estudante relaciona os argumentos apresentados pelo especialista com os exibidos anteriormente. Ao estabelecer essa relação, o educando busca fundamentar seu ponto de vista nas afirmações de autoridade.

Sumarizando, vale ressaltar que o discente apresentou, no primeiro parágrafo, a situação da sociedade e uma introdução à resposta proposta no título. No segundo parágrafo, ele desenvolveu a resposta buscando demonstrar que a violência pode ser cultural ou biológica. Nos dois parágrafos seguintes, o educando desenvolveu seus argumentos com base na fala de um especialista e agregou maior credibilidade à sua argumentação. $O$ educando produz o último parágrafo retomando o argumento de que a violência é resultado de raízes culturais e biológicas. Além disso, comenta uma possível solução para diminuir esses índices alarmantes da violência: educação. Entretanto, o aluno ressalta o fato de que, mesmo com a influência da educação, o ser humano ainda pode responder aos seus impulsos devido às circunstâncias da vida, conforme o ponto de vista defendido durante todo o texto e retomado no último parágrafo. 


\section{$\mathrm{EI} \square \mathrm{\alpha A}$}

Revista Eletrônica de Estudos Integrados em Discurso e Argumentação, Ilhéus, n. 17, jul./dez. 2018

Dentre as estratégias discursivas para a construção da conclusão, mencionadas por Koch e Elias (2016), podemos notar que o aluno utilizou, parcialmente, duas. O educando primeiramente elaborou uma síntese retomando os argumentos desenvolvidos anteriormente e, em seguida, apresentou uma possível solução para diminuir a violência: a educação. Vale ressaltar que, mesmo expondo a solução, o aluno concluiu que a origem agressiva do humano supera até mesmo a sua sugestão, o que reforça a tese desenvolvida durante toda a carta de leitor.

\section{Considerações finais}

O presente trabalho buscou contribuir para o ensino de produção textual à luz dos pressupostos da Teoria Semiolinguística do Discurso. Em vista disso, fundamentamo-nos nos princípios desta teoria para a formulação das etapas da Sequência Didática e para a elaboração do parâmetro de análise. Em busca de melhorar a argumentação presente nas cartas de leitor do educando focalizado, diferentes questões sobre a linguagem, à luz dos pressupostos do contrato de comunicação, foram propostas para os alunos com o objetivo de levá-los à reflexão dos diferentes mecanismos linguísticodiscursivos para a construção de uma boa argumentação, segundo os postulados descritos por Charaudeau (2014).

O discente Anderson apresentou um grande progresso quanto à produção de sua carta de leitor, conforme elucida o comparativo entre a primeira e a última produção, disposto no Quadro 2:

\section{Quadro 2 - Comparativo de produção}

\begin{tabular}{|c|c|c|c|}
\hline \multirow[t]{2}{*}{$\begin{array}{c}\text { Consistência } \\
\text { Argumentativa }\end{array}$} & $\begin{array}{c}\text { Modo } \\
\text { argumentativo } \\
\text { (Macroestrutura) }\end{array}$ & \multirow{2}{*}{$\begin{array}{l}\text { A carta não } \\
\text { responde ao } \\
\text { exercício } \\
\text { proposto, os } \\
\text { argumentos são } \\
\text { inconsistentes e } \\
\text { não apresenta } \\
\text { conclusão. }\end{array}$} & \multirow{2}{*}{$\begin{array}{l}\text { A carta é composta por } \\
\text { tese, argumentos e } \\
\text { conclusão bem sucedidos. } \\
\text { Os argumentos são } \\
\text { compostos por recursos } \\
\text { de autoridade e a } \\
\text { conclusão propõe uma } \\
\text { solução. }\end{array}$} \\
\hline & $\begin{array}{c}\text { Modo de } \\
\text { tematização } \\
\text { (Repertório/saberes) }\end{array}$ & & \\
\hline
\end{tabular}

Fonte: elaboração própria

Reconhecemos que as produções textuais do educando ainda possuem características que precisam ser aperfeiçoadas, todavia, o aprimoramento de 
seu texto é notório. Em vista disso, podemos concluir que as reflexões e os exercícios à luz da Teoria Semiolinguística do Discurso realizados em sala de aula, no bojo da Sequência Didática construída e aplicada, contribuíram para uma mudança expressiva nas cartas de leitor do estudante, confirmando a hipótese levantada no início deste trabalho. O ensino de produção textual filiada ao gênero carta de leitor - mediado pelo conhecimento das restrições do contrato comunicativo contribuiu, significativamente, para o desenvolvimento da produção textual do educando. Além disso, a tomada de consciência das restrições comunicativas e discursivas ajudou o aluno a planejar melhor as estratégias discursivas que contribuíram para o alcance do sucesso dos seus objetivos comunicativos em suas cartas de leitor.

Encerramos este trabalho com a expectativa de termos contribuído para o ensino de produção textual. Durante toda a pesquisa, buscamos aliar a Teoria Semiolinguística do Discurso à prática real do ensino da produção de textos na sala de aula. Por intermédio dos resultados, concluímos que é possível a aplicação dos pressupostos desenvolvidos neste trabalho em busca de empoderar os estudantes de um fazer por meio de um dizer mais consistente, adequado e claro.

\section{Referências}

BRASIL. Ministério da Educação e do Desporto. Parâmetros Curriculares Nacionais: Língua portuguesa: Ensino médio. Brasília: MEC/SEF, 2001.

CHARAUDEAU, Patrick. Visadas discursivas, gêneros situacionais e construção textual. [2001]. Tradução: Renato de Mello. In: MACHADO, Ida Lúcia; MELLO, Renato de. (org.). Gêneros: Reflexões em Análise do Discurso. Belo Horizonte: NAD/FALE/UFMG, 2004. p. 13-41.

. Uma análise semiolinguística do discurso. [1995]. Tradução: Angela Maria da Silva Corrêa. In: PAULIUKONIS, Maria Aparecida Lino; GAVAZZI, Sigrid (org.). Da língua ao discurso: reflexões para o ensino. Rio de Janeiro: Lucena, 2005. p.11-29.

. Discurso das mídias. [2005]. Tradução: Angela Maria da Silva Corrêa. São Paulo: Contexto, 2006.

. Linguagem e discurso: modos de organização. [2008]. Coordenação da tradução: Angela Maria da Silva Corrêa e Ida Lúcia Machado. São Paulo: Contexto, 2014. 
; MAINGUENEAU, Dominique. Dicionário de Análise do Discurso.[2004]. Coordenação da tradução: Fabiana Komesu. São Paulo: Contexto, 2004.

DOLZ, Joaquim; SCHNEUWLY, Bernard. Gêneros orais e escritos na escola. [2004]. Tradução e organização: Roxane Rojo e Glaís Sales Cordeiro. Campinas: Mercado das Letras, 2011.

EMEDIATO, Wander. A fórmula do texto: redação, argumentação e leitura. São Paulo. Geração Editorial, 2007.

KOCH, Ingedore G. V.; ELIAS, Vanda Maria. Escrever e argumentar. São Paulo: Contexto, 2016.

\section{Forma de citação sugerida}

RIBEIRO, Patricia Ferreira Neves; SOUZA, Diniz Duarte de Souza Duarte de. Argumentação e ensino: a mediação da teoria semiolinguística do discurso. EID\&A Revista Eletrônica de Estudos Integrados em Discurso e Argumentação, Ilhéus, n. 17, p. 122-140, jul./dez.2018. DOI dx.doi.org/10.17648/eidea-17-2133. 